\title{
IMPROVING STUDENTS' SPEAKING SKILL BY USING THREE STEP INTERVIEWS AT LINTASAN IMAJINASI BAHASA MAHASISWA (LIBAM) IAIN PAREPARE
}

\author{
Ramadhan $\operatorname{Aras}^{1}$, Magdahalena ${ }^{2}$, Abd. Rauf Ibrahim ${ }^{3}$ \\ English Program, Tarbiyah Faculty, State Islamic Institute of Parepare ${ }^{123}$
}

\begin{abstract}
English as primary and foreign language has become the key to the world. However, it must be found the way how to be mastered it. One of the skills which are very important is speaking skill because it will help people to communicate and interact each other. This research was carried out at LIBAM IAIN Parepare. In this case, the researcher found that some members of LIBAM IAIN Parepare are still a law in speaking especially in front of their friends or other people. To solve the problem, the researcher used three step interviews. This technique is one of student center learning which learners help each other and learn. The objective of the research is to know whether three step interviews is able or not to improve the speaking skill of members of LIBAM IAIN Parepare.

The population was the members of LIBAM IAIN Parepare and the sample of this research was 25 members. The researcher used pre-experimental design in one group was given pre-test, treatment and post-test design, as for the effect of treatment was judged by the difference between the pre-test and post-test. The success of the treatment is determined by comparing pre-test and post-test score. To collect the data, the researcher used tests that are pre-test and post-test. The researcher also gave questionnaire to know the responses of students to three step interviews. The data were analyzed as a percentage, mean score analyzes and the value of the test.

The first result of the data analyzed that the students' achievement on the pretest was (6.36) and post-test was (7.26) This showed that by using three step interviews was a good technique in English learning process at Lintasan Imajinasi Bahasa Mahasiswa (LIBAM) IAIN Parepare. After analyzing the data by using the ttest formula, the result of the t-test value (9.64) is bigger than the t-table value (1.71). It means that there is a different improvement before and after using three step interviews as technique of teaching. The second result of analyzed data that $72 \%$ of the students were interested in using three-ste interview, in the other word most of them interested to apply three stepinterviews.
\end{abstract}

Keywords: Speaking Skill, Three Step Interview 


\section{Introduction}

Speaking is one of the four skills in English that have to be mastered by the students. It can be a tool for the students to communicate. The students can get the other information from other students through speaking. Speaking is a verbal communication of language use to communicate with others. The students can tell or convey of their information or problems from their mind ideas through speaking.

Speaking helps students to make them be talk-active so that they can share what they know or what they do not know are about the case they are faced. In addition, speaking is the way to express ideas and opinion, to send expression or desire to do something, to solve some a particular problem, to increase the proficiency in speaking and to maintain the relationship or friendship. So, speaking is an important skill of language which should have improves for the students. From the definition above it can be conducted that speaking is one skill must be mastered by students to send or to receive the information or message, to communicate and so on. In reality, there are still many students difficult to speak in English especially for members of LIBAM. Most of them could not speak English well because of several reasons. Firstly, they felt difficult to convey their words to other because they confuse to convey or to say what. Secondly, they are shy to speak because of mispronounce wordsand thirdly not confidence. Finally, the students are lack of vocabularies. There are many also ways to improve speaking skill or deducttheproblem in learningspeaking.

Based on those problems and the class condition above, intends to help the English teacher by introducing one of Collaborative Teaching Learning model namely, Three-Step Interview to improve students' speaking skill. Barkley, et al stated that, practice of Collaborative learning technique has come to mean students working pairs or small groups to achieve shared learning goals. It is learning through group work rather than learning by working alone. Supported by Kayi, agreed that working in groups could create a classroom environment where students have real-life communication, authentic activities, and meaningful tasks 
that promote oral language. Based on the statement, the researcher chooses one of Collaborative learning technique namely Three-Step Interview.

In State Islamic Institute (IAIN) Parepare there is an organization named Lintasan Imajinasi Bahasa Mahasiswa (LIBAM) which supports and improves the English skills and Arabic skills of its member. The researcher done preliminary observation on LIBAM's member activities especially in English learning process especially in teaching speaking and found that some members of LIBAM were unmotivated and difficult to learn. Their mindsets say English is difficult to learn because most of them don't know how to express what they want to say and some their instructors do not use variation technique. In teaching and learning English, it needs to apply many techniques to improve the learners' skill. One of the techniques which have not been applied is three step interviews. Hence, the researcher chooses three step interviews, because the students will be easier to express their ideas to others.

Speaking is an interactive process of constructing meaning that involves producing and receiving and processing information. Its form and meaning are dependent on the context in which it occurs, including the participants themselves, their collective experiences, the physical environment, and the purposes for speaking. It is often spontaneous, open-ended, and evolving (Brown, 2019). Speaking is the action of conveying information or expressing one's thoughts and feelings in spoken language (Webster's Comprehensive Dictionary, 2003). Speaking is a skill which is chosen as an object to be improved in this research. Carter and Nunan stated that, speaking in a second language involves the development of a particular type of communicationskill (Kurniawati, 2016).

Clark and Clark define that communication deals with two basic activities: listening and speaking. In speaking, people express their thoughts through words and talkaboutperceptions, feelingsandintentionstheywantotherpeopletograspand understand. Meanwhile, Spratt points out that using speech to convey meaning to others is involved in speaking (Clark \& clark,2013).

Kagan stated that three-step interview is another simple information sharing structure. It consists of three steps and works best in groups of four but 
can be adapted for larger or smaller groups. Lipton. L stated that The Three- Step Interview is a cooperative structure that helps students personalizes their learning and listen to and appreciate the ideas and thinking of others. Active listening and paraphrasing by the interviewer develops understanding and empathy for the thinking of the interviewee.Theycanbeusedasanintroductiontoanactivityorawaytoexplore ideas and concepts more deeply. Students also have an opportunity to develop active listening skills and understand others' viewpoints (Setiadi, 2015).

Barkley, Cross, and Major stated the benefits of Three-Step Interview, Three- Step Interview is an effective strategy for drawing out students' experience knowledge from outside of class. Used this way, it can help motivate students because it bridges the gap between the academic and the real world. This statement made the researcher curious to implement it in the class to improve the students' speakingability (Kurniawati, 2016). Three Steps Interview technique will give benefits to the students as follows:

1. Three-Step Interview creates simultaneousaccountability

2. Students share and apply different questioning strategies, and

3. Over time, students can be introduced to different taxonomies of thinking to extend their ability to use different levels of questioning andthinking. (Permanasari, 2014)

The aims of Three Steps Interview technique is to engage students in conversation for the purpose of analyzing and synthesizing new information. Three- Step Interview is a strategy that is effective when students are solving problems that have no specific right answers. Three problem-solving steps are involved in this process.

Three-Step interview promotes a simple method to ensure individual accountability. The procedure drives students to be active in the learning process. Consequently, they will get experience in the teaching and learning process. The following is the procedure of Three-Step interview implementation in the classroom based on Barkley, Cross, and Major, as follow: 
1. Students divide into groups of four, and quads subdivide into pairs A-B and C- D.

2. StudentanInterviewsBandstudentCInterviewsDforapredeterminedtime. The interviewer asks questions, listens, and probes for further information but does not evaluate or respond.

3. Partners reverse roles and interview each other for the same amount oftime.

4. Students A and B introduce each other with synthesized summaries of their partner's interview responses to Students $C$ and D. Student C and D do the same for Students A and B.

Three-Step Interview has detail steps. If the teacher did not guide the action, the class will be uncontrolled. And the students will not get the advantages after implemented it.

\section{Method}

The method applied is a pre-experimental method with one group pre-test and post-test design, this is presented as follow:

$$
\begin{array}{lll}
\mathrm{O}_{1} & \mathrm{X} & \mathrm{O}_{2}
\end{array}
$$

Where:

$\mathrm{E}=$ Experimental

$\mathrm{O} 1=$ pre-test

$\mathrm{X}=$ Treatment

$\mathrm{O} 2=$ Post-test

In this experimental design, the effect selected teaching materials implementation was found out by comparing the result of the students' achievement in pre-test andpost-test.

The population of this research were the members of LIBAM IAIN Parepare in 2018. It has consisted 142 members. The researcher's reason took this organization to be population and sample because it has some students which 
have different majors, the researcher is also one of LIBAM IAIN's Member. Therefore, the researcher knew all situations there.

The study used sample random in this research. The sample of this research has consisted 25 samples form 142members. Steps of collecting data as follows:

\section{Pre-test}

The pre-test is an oral speaking test where the students are interviewed by other students. Student A became interviewer and studen B became interviewee. Then exchanged interviewer became interviewee and interviewee became interviewer. The pre-test is used to check the students' speaking ability before giving treatment. Before giving the treatment and this test is given to find out the initial skill or ability before implementing three step interviews.

\section{Treatment}

The treatment conduct after pre-test has given in the classroom. The materials gave based on the syllabus. The researcher applied the procedure of each activity.

\section{Post test}

After doing the treatment, the researcher gave the post-test to the student. It is aimed to identify the influence of three step interview in achievement speaking skill of members of LIBAM IAINParepare.

\section{Result}

To find out the answer to the research question in the previous chapter, the researcher administered a test. The test was a speaking test that was given twice the test are pre-test and post-test.

The researcher has given pre-test to know the students' speaking skill before treatment by applying three-step interview. The students were difficult to speak well in the pretest, that's why they have to get some treatments to improve the students' speaking skill. in this research the researcher gave 6 meetings to treat students. Based on the result of pre-test analysis in the table above, it showed that there are 4 students got poor, there are 19 students got fair and there are 2 
students got good. However, the average score is 159 from the overall students achieved of their speaking. It is described that the quality of the students' speaking skill is still poor before getting a treatment. After determining the mean score of pre-test was 6.36 it could be seen that student's speaking skill was in faircategory.

The researcher has given post-test to know the students speaking skil after giving treatment by applying three-step interview for 6 six meetings. Most of them were better than before. They can speak English fluently with a good pronounce. Based on the result of the post-test analysis in the table above, it showed that there are 2 students got eexcellent, there are 6 students got fair and most of them got good category. However, the average score is 181.7 from the overall students achieved of their speaking. It described that the quality of the students' speaking skill is good. They got an improvement after getting treatment by using three-step interview. After determining the mean score of pre-test was 7.26 it could be seen that student's speaking skill was in a good category.

The students got improvement by gaining score before and after treatment. It proved that the students got improvement in their speaking skill by using threestep interview. The improvement can be measured by presenting the minimum and maximum score of pre-test and post-test. The minimum score of pre-test was 5.40 and the maximum was 7.30, beside that the minimum score of post-test is 6.70 and the maximum score of post-test is 8.70. The mean of pre-test is 6.36 and the mean of post- test is 7.26. Before treatment the students got fair category but after doing treatment by using three-step interview the students got good category, it means that there are improvements with students' speaking skill.

\section{Conclusion}

The research of data analysis showed that three step interviews is able to help students personalize their learning and listen to and appreciate the ideas and thinking of others and it was also described that this material was an effective way when the students are solving problems that have no specific right answers.

The data analysis test also showed that there was a difference between the students' speaking skill before and after applying "Three step interview", it was 
proved by the development of mean score from 6.36 on the pre-test to 7.26 on post- test. Therefore, three step interviewswere able to improve the students' speaking skill of the members' LIBAM IAIN Parepare.

\section{References}

Akkas, Alim. 2015. Improving Speaking Skills Through Peer Tutoring Strategy at Member of YMPI English Meeting Club (YEMC) At Mts Ympi Rappang Kabupaten Sidrap. Unpublished Skripsi STAIN Parepare.

Arikunto, Suharsimi. 2005. Dasar-Dasar Evaluasi Pendidikan (edisi revisi). Jakarta: PT. Bumi Aksara.

Astrianto, Setiadi Muhammad. 2015. Improving Student's speaking ability through three step interview method. Unpublished Thesis Muhammadiyah Makassar Univercsity.

Brown dkk. 1997. area.dge.mec.pt/gramatica/whatspeakingis.htm. assessed on 22 January. 2019

Brown, Gillian and George Yule. 1989. Teaching the Spoken Language: Approach Based on the Analysis of conversational English. Australia: Cambridge University Press.

Brown, H. Doughlas. 1994. Teaching by Prinsiple; an Iinteractive Approach to Language Pedagogy. U.S.A: A Paramount Communications Company.

Candrakirana, Permanasari Rani. 2014. Improving Student's speaking skill through three step interview technique. Unpublished skipsi Semarang state university.

Gay, L.R. 1987. Educational Research. New York: Charles Merril Publishing Company.

Hammer Jeremy. 1998. The Practice of English Language Teaching. London and New York: Longman.

Jones, Rhodi. 1989. Speaking and Listening. London: The Bath Press.

Kumara, Silva Prucesia. 2013. Improving Student's speaking skill through the use of video clips. Unpublished Thesis State university of Yogyakarta.

Noviasari, Rindawati. 2014. Teaching speaking through talking stick method. Unpublished Journal Bung Hatta unviversity. 
Nukhaq, Kurniawati Ullin. 2016. Improving Student's speaking ability by using three step interview of the tenth grade students at SMK PGRI 1 TULUNGANGUNG in academic year 2015/2016. Unpublished Skiripsi IAIN Tulungangung.

Saepudin, et al., eds. 2013. Pedoman Penulisan Karya Ilmiah (Makalah dan Skripsi). Parepare: Sekolah Tinggi Agama Islam Negeri Parepare.

Shinta, Dewi Eva. 2015. Improving speaking skill through numbered headstogether of the seventh grade students of smp pgri 4 denpasar in academic year 2014/2015. Unpublished journal Denpasaruniversity.

Sugiono. 2010. Metode Penelitian Pendidikan. (Pendekatan Kuantitatif, kualitatif, dan $R \& D)$. Bandung: Alfabeta.

Syofian,Siregar. 2013. Metode Penelitian Kuantitatif Dilengkapi Perhitungan Manual \& SPSS. Penerbit: Kencana PrenamediaGroup.

Webster's, Comprehensive Dictionary. 2003. The new International Webster's comprehensive of the English language.Trident press International.

Wulandari, Wahyuni, Abu Bakar Juddah, Abdul Haris Sunubi. 2018. Psychological Barriers and Their Influence Towards Students' Speaking Ability. Journal Inspiring: Vol. 1 No. 12018. 